\title{
PENGELOLAAN LIMBAH DOMESTIK BERBASIS KOMUNITAS DI KAWASAN DAERAH ALIRAN SUNGAI TAWING: Studi Kasus Di Kabupaten Trenggalek
}

\begin{abstract}
Windiani* $^{*}$
Abstrak

Penelitian tentang pengelolaan limbah domestik berbasis komunitas Di kawasan Daerah Aliran Sungai (DAS) Tawing ini didasarkan pada fenomena bencana banjir yang terjadi hampir setiap tahun. Faktor penyebabnya tidak hanya karena faktor alam namun juga disebabkan adanya penurunan daya resap dan pendangkalan sungai di berbagai daerah. Hal ini terkait juga dengan kebiasaan, kesadaran, sikap dan perilaku masyarakat terhadap lingkungan yang masih rendah. Sebagian masyarakat di kawasan daerah aliran sungai Tawing masih membuang limbah domestiknya, baik kotoran maupun sampah rumah tangga ke sungai. Hal ini lebih disebabkan persepsi yang berkembang dalam masyarakat bahwa sungai berfungsi sebagai halaman belakang (backyard) sehingga sungai digunakan sebagai tempat pembuangan limbah. Di sisi lain keberadaan komunitas pemuda pecinta lingkungan di daerah di Kabupaten Trenggalek berdampak positif jika peran dan kapasitas komunitas tersebut dikembangkan terutama terkait dengan upaya pemberdayaan masyarakat dalam mengelola limbah domestiknya. Hasil penelitian menunjukkan bahwa pengelolaan limbah domestik yang dilakukan adalah aplikasi 3R (Reuse, Reduce dan Recycle) dengan kelompok sasaran: komunitas lbu rumah tangga, Komunitas Petani, komunitas Guru dan pendamping dan Komunitas pemuda karang taruna. Strategi yang dikembangkan dalam pengelolaan limbah domestik meliputi: Perencanaan dan Program Pengembangan, Penguatan kelembagaan dan Pengembangan jaringan dan kerjasama. Hingga saat ini pengolahan limbah domestik menjadi pupuk organik, larangan meracuni sungai Tawing dan pemberian sanksi kepada masyarakat yang membuang sampah merupakan program yang sudah berjalan, namun dipandang perlu untuk dikembangkan dengan sasaran wilayah yang lebih luas. Sosialisasi secara intens dan pendampingan kepada kelompok sasaran perlu terus dilakukan agar terjadi keberlanjutan program.
\end{abstract}

Kata Kunc: Pengelolaan, Limbah domestik, Komunitas Pemuda, Daerah Aliran Sungai(DAS)

Daerah Aliran Sungai (DAS) merupakan modal pembangunan nasional yang sangat penting dan bermanfaat bagi kehidupan dan penghidupan manusia. Namun dalam kenyataannya tidak jarang kawasan ini dipandang sebagai "tempat pembuangan akhir" dari sampah-sampah yang dihasilkan terutama berasal dari sampah rumah tangga (limbah domestik). Persepsi dan Perilaku masyarakat setempat yang masih belum berorientasi pada pentingnya mengelola limbah domestik terutama di kawasan Daerah Aliran sungai dapat berdampak buruk terhadap kualitas lingkungan dan kualitas air yang menjadi sumber penghidupan

\footnotetext{
* Dosen UPM oshum ITS
}

jsh Jurnal Sosial Humaniora, Vol 4 No.1, Juni 2011 
manusia. Jika kondisi ini terus diabaikan akan beresiko terjadinya kerusakan lingkungan seperti banjir dan buruknya kualitas air sungai yang menjadi sumber kehidupan bagi sebagain besar masyarakat yang mayoritas menyandarkan diri pada sektor pertanian.

Sungai Tawing merupakan salah satu sungai yang ada di Kabupaten Trenggalek, berhulu di Kecamatan Kampak dan melintasi 10 desa dari dua kecamatan yaitu kecamatan Kampak dan Kecamatan Gandusari. Berdasarkan hasil observasi di lapangan, secara kasat mata kondisi sungai Tawing mengalami kualitas penurunan yang sangat signifikant terutama jika dilihat dari kualitas lingkungan di sekitar kawasan sungai yang dijadikan sebagai tempat pembuangan sampah oleh masyarakat setempat. Hampir di sepanjang sungai terdapat pemandangan yang sangat memprihatinkan dengan sampah berserakan yang tidak dikelola. Indikasi lain dapat dilihat dari warna air yang cenderung keruh di musim kemarau serta banyaknya sampah plastik yang terikut dan bau air yang menyengat.

Sejalan dengan visi-misi Bupati terpilih tahun 2010-2011, Kabupaten Trenggalek menetapkan isu-isu strategis dalam pembangunan antara lain bidang: Pelayanan publik, Pendidikan, Kesehatan, Tenaga kerja, Lingkungan Hidup, Pertanian dan Kelautan serta infra struktur dan Pengembangan wilayah maka upaya penelitian yang mencakup strategi pemberdayaan komunitas yang peduli terhadap lingkungan menjadi relevan untuk dilakukan.

Isu strategis dalam bidang lingkungan di kabupaten Trenggalek salah satunya didasarkan pada alasan bahwa terjadinya bencana alam banjir dan tanah longsor di Kabupaten Trenggalek setiap tahun telah menimbulkan banyak kerugian dan menyengsarakan banyak warga. Kondisi anomali cuaca dan perubahan iklim akibat pemanasan global ditambah sikap dan perilaku masyarakat yang belum adaptable terhadap perubahan-perubahan yang terjadi di lingkungan sekitar memperparah terjadinya permasalahan-permasalahan lingkungan yang berampak pada semakin intensnya bencana alam seperti banjir, tanah longsor, erosi, badai tropis dan kekeringan.

Persoalan masih belum adaptable-nya sikap dan perilaku masyarakat ini yang menarik peneliti untuk mengkaji lebih mendalam terutama dalam kaitannya 
dengan semakin kompleksnya fenomena sampah yang ada di sekitar kawasan Daerah Aliran sungai (DAS). Jika ini terus dibiarkan persoalan banjir bukan hanya sekedar masalah fenomena alam akibat perubahan iklim dan pemanasan global, namun juga disebabkan karena masih rendahnya sikap dan perilaku masyarakat dalam menjaga kelestarian lingkungan.

Sasaran dari penelitian yang dikehendaki adalah komunitas pemuda pecinta lingkungan, karena peneliti berasumsi bahwa Komunitas pemuda pecinta lingkungan memiliki kepedulian dan motor penggerak perubahan. Sehingga diperlukan upaya untuk strategi pemberdayaan di kalangan pemuda pecinta lingkungan untuk melakukan sesuatu yang bermanfaat dalam mengatasi masalah lingkungan khususnya terkait dengan fenomena sampah di kawasan Daerah aliran Sungai (DAS). Konsep Strategi pengelolaan yang dikembangkan melalui konsep umum yang sudah diterapkan di banyak wilayah dalam mengelola sampah domestik dengan model 3R : Reduce, Reuse dan Recycle.

Melalui komunitas Pemuda pecinta lingkungan yang ada diharapkan menjadi agent of change karena komunitas tersebut memiliki kepedulian yang tinggi terhadap lingkungan termasuk masalah sampah yang dihasilkan dari aktivitas rumah tangga (domestik). Aksi nyata yang sudah dilakukan komunitas pemuda pecinta lingkungan ini antara lain adalah: Gerakan Pungut Sampah di Pantai Prigi setiap akhir tahun (DPR Comunnity, 2010).

Tulisan ini merupakan hasil penelitian yang dilakukan di kabupaten Trenggalek dengan fokus permasalahan pada bagaimana pengelolaan limbah domestik yang diterapkan masyarakat di kawasan daerah aliran Sungai Tawing. Penelitian ini dipandang penting dilakukan khususnya untuk menjawab isu strategis lingkungan yang sudah diagendakan dalam pembangunan pada tahun 2010-2015 yang akan datang. Di samping itu, menarik untuk mengkaji lebih mendalam bagaimana peran dan kontribusi komunitas pecinta lingkungan dalam mengelola limbah domestik. Serta strategi apa yang dikembangkan untuk upaya pemberdayaan komunitas pemuda pecinta lingkungan tersebut untuk meningkatkan kualitas lingkungan khususnya di kawasan DAS Tawing di Kabupaten Trenggalek. 


\section{Tinjauan Pustaka}

Pembangunan berkelanjutan (Sustainable development) adalah suatu proses pembangunan yang mengoptimalkan manfaat dari Sumber Daya Alam dan Sumber Daya Manusia dengan menyerasikan sumber alam dengan manusia dalam pembangunan. Pembangunan Berkelnjutan in merupakan suatu program reformasi ekonomi lokal dan global sebagai reaksi atas kesenjangan-kesenjangan yang terjadi. Tantangan dari pelaksanaan pembangunan berkelanjutan adalah untuk mengembangkan dan menguji cara-cara untuk mengubah proses pembangunan ekonomi agar tidak membawa kehancuran ekologis dan system komunitas serta menciptakan kehidupan yang lebih berkualitas (Mukhtasor, 2008). Penerapan Pembangunan Berkelanjutan dalam hubungannya dengan ekosistem, antara lain dengan : 1. Konservasi dan Preservasi, 2. Efisiensi sumber daya, 3. Mereduksi limbah, 4. Teknologi tepat guna.

\section{Pengelolaan Limbah}

Terkait dengan limbah domestik yang meningkat baik volume dan jenisnya, perlu kiranya mempertimbangkan strategi pemanfatan limbah yang sudah berkembang di berbagai wilayah. Pemanfataan limbah akan sangat membantu dalam mengurangi jumlah limbah yang ada di lingkungan. Pemanfataan limbah berarti memberikan nilai tambah pada limbah yang semula tidak mempunyai nilai ekonomi menjadi bahan yang mempunyai nilai ekonomi. Pemanfaatan limbah dapat dikelompokkan menjadi tiga jenis kegiatan yaitu: Mengurangi (Reduce), Penggunaan kembali (Reuse) dan Daur Ulang (Recycle) (Muktasor,ed, 2009).

Mengurangi (Reduce): dapat dilakukan oleh setiap orang dengan cara mengurangi penggunaan barang-barang yang dapat meningkatkan volume limbah. Misalnya limbah atau sampah plastik; ibu rumah tangga dapat mengurangi penggunaan tas plastik 'kresek' ketika berbelanja di pasar dengan meminta kepada penjual cukup satu tas 'kresek' untuk berbagai jenis belanjaan yang bisa disatukan. Hal ini bisa mengurangi volume sampah atau limbah domestik khususnya sampah plastik. 
Penggunaan Kembali (Reuse): penggunaan kembali adalah pemanfataan limbah dengan jalan menggunakannya kembali untuk keperluan yang sama atau fungsinya sama, tanpa mengalami pengolahan fisik/kimia atau biologi atau perubahan bentuk. Misalnya: kaleng cat yang besar, dapat digunakan kembali untuk mengangkut air, Tas plastik yang masih bagus dapat digunakan kembali oleh ibu-ibu rumah tangga untuk berbelanja dsb.

Daur Ulang (Recycle): Upaya daur ulang dapat dilaksanakan dengan perolehan kembali dan penggunaan kembali, yang dilaksanakan melalui pengolahan fisik, kimia dan biologi untuk menghasilkan produk yang sama atau produk lain. Contoh: Besi bekas diolah kembali menjadi barang-barang besi, dapat berupa barang yang sama maupun barang lain. Plastik didaur ulang menjadi mainan anakanak. Sehingga proses baik reduce, reuse dan recycle ini dapat berdampak secara langsung terhadap kualitas lingkungan khususnya dapat terkuranginya volume sampah yang ada dan dapat bernilai secara ekonomis bagi yang mengolah atau mamanfaatkanya.

\section{Pemberdayaan Komunitas}

Sejalan dengan program pembangunan berkelanjutan, keterlibatan komunitas menjadi hal yang penting untuk meningkatkan kapasitas, peningkatan ekonomi dan peningkatan kualitas lingkungan itu sendiri. Mosse (1996) menekankan pentingnya pendekatan pemberdayaan (empowerment) dalam paradigma pembangunan. Pembangunan dalam konteks ini harus melibatkan komunitas atau masyarakat setempat. Jika komunitas setempat diberi kesempatan didengar, diminta pendapat serta dilibatkan dalam perencanaan dan penerapan proyek pembangunan, dampak dan keuntungan pembangunan bagi seluruh komunitas akan lebih besar.

Pemberdayaan komunitas dipahami secara khusus sebagai: perubahan sosial yang terencana dan relevan dengan persoalan-persoalan lokal yang dihadapi oleh para anggota sebuah komunitas (a locality-relevant planned change) yang dilaksanakan secara khas dengan cara-cara yang sesuai dengan kapasitas, norma, nilai, persepsi, dan keyakinan anggota komunitas setempat, dimana prinsip-prinsip resident participation dijunjung tinggi. 
Tap MPR RI/NO/2002 menetapkan bahwa dengan memperhatikan permasalahan sumber daya alam dan lingkungan hidup dewasa ini, pengelolaan di bidang pelestarian lingkungan hidup mempunyai beberapa ciri khas, yaitu tingginya potensi konflik, tingginya potensi ketidaktentuan (uncertainty), kurun waktu yang sering cukup panjang antara kegiatan dan dampak lingkungan yang ditimbulkan, serta pemahaman masalah yang tidak mudah bagi masyarakat luas. Karena ciri-ciri ini, usaha pelestarian akan selalu merupakan suatu usaha yang dinamis, baik dari segi tantangannya yang dihadapi maupun jalan keluarnya merekomendasikan untuk menerapkan prinsip-prinsip good environmental governance secara konsisten dengan menegakkan prinsip-prinsip rule of law, tranparansi, akuntabilitas, dan partisipasi masyarakat. Dalam hubungan ini, perlu diusahakan agar masyarakat umum sadar dan mempunyai kesadaran pada kelestarian lingkungan hidup, mempunyai informasi yang cukup tentang masalah-masalah yang dihadapi, dan mempunyai keberdayaan dalam berperan serta pada proses pengambilan keputusan demi kepentingan orang banyak.

Sejalan dengan otonomi daerah, pelimpahan wewenang kepada pemerintah daerah di bidang pengelolaan sumber daya alam dan pelestarian lingkungan mengandung maksud untuk meningkatkan peran masyarakat lokal dalam pengelolaan lingkungan hidup. Peran serta dalam intensitas tinggi oleh masyarakat umum inilah yang dapat menjamin dinamisme dalam pengelolaan lingkungan, sehingga pengelolaan ini mampu menjawab tantangan tersebut di atas. Mekanisme peran serta masyarakat ini perlu termanifestasikan dalam kehidupan sehari-hari melalui mekanisme demokrasi.

\section{Peran Komunitas Dalam Pengelolaan Limbah Domestik}

Fenomena lingkungan, yang jenuh akibat semakin meningkatnya baik volume maupun jenis limbah rumah tangga baik organik atau non organik. Keberadaan limbah sampah dirasakan kian menjadi permasalahan lingkungan yang harus mulai dipikirkan pemecahan penanganannya secara mandiri di tingkat lingkungan. Karena, tidak mungkin selalu mengandalkan pihak lain, dalam hal ini pemerintah, untuk menangani sampah. Apalagi di pedesaan, pengelolaan sampah biasanya tidak terjangkau karena jauh dari fasilitas pembuangan sampah yang ditangani oleh pemerintah. Akhirnya mau tidak mau masyarakat sendirilah yang harus mengelola sampah secara mandiri. Dengan sentuhan kreatifitas, sebenarnya 
fenomena sampah dapat dijadikan peluang ekonomi dengan menggunakan model pemilahan, pengolahan daur ulang sehingga memiliki daya jual di pasaran,.

Berdasarkan hasil penelitian di lapangan tidak ditemukan berapa angka pansti dari volume sampah yang dihasilkan setiap harinya di kecamatan Kampak kabupaten Trenggalek, namun kenyataan di lapangan menunjukkan bahwa sebagian masyarakat masih membuang sampah di sungai atau anak sungai yang terdekat dengan rumah. Belum ada managemen pengelolaan yang lebih bersifat ramah lingkungan dan memiliki nilai ekonomis bagi masyarakat. Di samping persepsi masyarakat yang keliru terhadap sampah menentukan sikap dan perilaku masyarakat terhadap sampah yang dianggap sesuatu yang harus dijauhi, tidak berguna dan kotor sehingga sampah harus dibuang. Demikian juga pandangan masyarakat terhadap sungai yang dipandang sebagai halaman belakang (backyard) sehingga sungai tidak terlihat dari depan kalaupun sungai digunakan untuk pembuangan limbah kotoran manusia maupun limbah rumah tangga.

\section{Model Pengelolaan:}

Model pengelolaan lingkungan yang dilakukan komunitas pemuda dalam mengelola limbah domestik lebih berbasis pada komunitas (komunitas petani, ibuibu rumah, dengan aplikasi Konsep 3R (Reduce, Reuse dan Recycle). Model ini dianggap lebih efektif dan mudah menyentuh akar permasalahan yang sesungguhnya karena melibatkan masyarakat secara langsung yang ada dalam komunitas. Dalam pengelolaan limbah domestik model berbasis komunitas ini, komunitas yang terlibat dan berperan sasaran:

1. Komunitas Ibu Rumah tangga; komunitas ini dipandang sangat penting rena komunitas ibu rumah tangga merupan kelompok sasaran utama kerena ibu rumah tanggalah yang paham dan berhadapan langsung dengan masalah limbah rumah tangga mulai dari volumenya dan jenis sampah yang ada dalam rumah tangga.

2. Komunitas Petani: merupakan kelompok sasaran yang bersentuhan langsung khususnya terkait limbah rumah tangga khususnya yang organik. Melalui pelatihan dan pemberdayaan diharapkan petani mampu mengolah sendiri 
sampah-sampah rumah tangga yang bisa dijadikan kompos sehingga mampu mengurangi ketergantungan petani terhadap pupuk kimiawi sekaligus mampu menekan biaya operasional untuk mengelola lahan pertanian. Di samping itu resiko penggunaan pupuk kimiawi yang terus-menerus digunakan yang dapat berakibat menurunnya kuliatas lingkungan khususnya hilangnya unsur hara dalam tanah atau lahan pertanian dapat diminimalisir.

3. Komunitas guru: Guru; merupakan kelompok sasaran strategis kerena dipandang mampu menyampaikan pesan secara langsung kepada siswanya dari berbagai jenjang. Kesadaran dan kepedulian terhadap lingkungan perlu ditanamakan sejak dini, agar kelak menjadi generasai yang peduli lingkungan termasuk pengenalan model peneglolaan sampah secara mandiri

4. Komunitas Pemuda: terdiri dari karang taruna, mahasiswa dan pelajar. Komunitas ini dipandang sangat penting untuk menjadi agent of change dalam memotori gerakan lingkungan yang saat ini menjadi bagian dari isu global (global warming).

\section{Strategi pengelolaan}

\section{Perencanaan:}

1. Bentuk kegiatan yang direncanakan Komunitas pemuda DPR Community adalah dalam Bentuk Pendampingan secara langsung di masyarakat bagaimana sistem dalam menabung dalam bentuk sampah, bukan bentuk uang.

2. Melakukan managerial baik administrasi dan management dengan pengawasan dan panduan dari Team ITM LPPM ITS Surabaya didalam pengelolaan bank sampah dalam bentuk Koperasi ( Misi menengah dalam program DPR Scooling ) sehingga bisa meningkatkan taraf pendapatan anggota DPR Community dan aset daerah. Hal ini dilakukan dengan

3. Identifikasi permasalahan dan Analisis terhadap:

- Revitalisasi Sumber Daya Manusia,

- Revitalisasi Kelembagaan, serta 
- Revitalisasi Teknologi dan Industri Hilir.

4. Investigasi adalah kegiatan peninjauan ke tempat kejadian untuk melihat langsung dan melakukan cross check terhadap kebiasaan masyarakat dalam membuang sampah, sekaligus mengumpulkan data dan informasi guna mengidentifikasi permasalahan, sasaran masyarakat, serta jenis bantuan yang diperlukan ( $M A P P I N G$ ).

Sehingga diperoleh suatu system pendeteksian dan pengelolaan informasi yang berjalan terus menerus tentang kebiasaan membuang sampah sembarangan dan pemahaman pemilahan sampah sejak dari hilir berdasarkan indikator letak wilayah, taraf kesehatan dan kemiskinan sehingga muncul kesadaran menabung dengan Sampah ke Bank Sampah DPR Community. Hasil dari pendampingan dan monitoring berupa Informasi program Bank Sampah

Dengan penjabaran sebagai berikut :

a. Memberikan pemahaman kepada masyarakat tentang Pemilahan Sampah Organik dan Non-organik sejak dari hilir dengan cara memberikan Sosialisasi kepada masyarakat tentang keberadaan Bank Sampah yang dapat menambah nilai produktif dan peningkatan pendapatan rumah tangga.

A. Monitoring

1. Bertujuan untuk memantau perkembangan kondisi dan penyebab, serta memantau pelaksanaan kegiatan untuk pencegahan dan penanggulangannya.

2. Monitoring bisa dilaksanakan dengan cara supervisi langsung maupun dengan pengisian form pelaporan

3. Laporan yang masuk dari kelompok ditindak lanjuti oleh team dengan memberikan pengarahan dan sosialisasi ulang.

B. Evaluasi

Bertujuan untuk menilai keberhasilan Program Bank Sampah

Kegiatan Evaluasi meliputi :

1. Pelaksanaan kegiatan (pengorganisasian, pengelolaan dan implementasi pemberdayaan) 
2. Upaya pencapaian tujuan

3. Dampak Bank Sampah terhadap pengembangan system ketahanan pangan dan perilaku masyarakat.

\section{Program dan aksi Peduli Lingkungan dari Komunitas Pemuda:}

1. Peduli Sampah: Sisir sampah di Pasir Putih Prigi: Clean My pasir Putih Beach

2. Kerjasama dengan Dinas Pertanian membuat pupuk organik dari sampah rumah tangga

3. Penanaman 1000 pohon di sekitar kawasan hutan rakyat di kecamatan Kampak

4. Larangan meracuni ikan di Sungai Tawing

5. Larangan menangkap ikan kecil di Sungai Tawing

6. Sosialisasi kepada masyarakat terhadap resiko sampah plastik terhadap lingkungan

7. Pelatihan dan pemberdayaan masyarakat dalam mengolah sampah rumah tangga dengan konsep; $3 \mathrm{R}$ Reuse, Reduce dan Recycle

3. Bentuk Kepedulian Masyarakat terhadap lingkungan yang sedang berjalan:

1. Larangan membuang sampah di sungai dengan memberikan sanksi (dikenakan denda 2 sak semen) sejak 2 tahun yang lalu (2009) khususnya di wilayah Desa Melis kecamatan Gandusari berjalan efektif dalam menjaga kualitas air di Sungai

2. Sebagian masyarakat sudah mampu mengolah limbah rumah tangga menjadi pupuk organik sehingga mengurangi ketergantungan pada pupuk kimiawi.

4. Tantangan:

1. Masih banyak masyarakat yang membuang sampah ke sungai dan anak sungai. 
2. Masih banyak masyarakat yang membuang air besar dan limbah MCk ke sungai dan anak sungai Tawing.

3. Sungai Tawing sering digunakan untuk membuang limbah kotoran ternak sapi ke sungai.

4. Masih banyak pedagang ayam potong di pasar Kampak yang membuang limbahnya (air bekas cucian daging), kotoroan ayam dan bulu ayam ke sungai Tawing.

5. TPA (tempat Pembuangan Akhir) sampah pasar berada di bibir sungai (sekitar 6 meter dari sungai), sehingga pada saat air sungai penuh dan meluap sampah terikut air sungai.

\section{Hambatan atau kendala yang dihadapi:}

1. Kendala yang dihadapi: keterbatasan pemuda yang konsisten memiliki kepedulian terhadap lingkungan,apalagi kalau pemuda yang peduli sudah memasuki jenjang keluarga. Hal ini yang sering menjadi kendala untuk mewujudkan konsep atau rencana-rencana yang akan dilaksanakan. Regenerasi/kaderisasi juga mengalami kendala meskipun berbagai upaya yang menarik dilakukan seperti membaut poster, mengikuti stand promo produk ramah lingkungan, karnafal dengan menggunakan barang-barang bekas dsb.

2. Dan kesulitan klasik yangdihadapi dalam menjalan program adalah keterbatasan anggaran serta akses-akses untuk mendapatkan pendanaan yang sulit untuk dilakukan secara mandiri jika kegiatan atau program membutuhkan pedanaan yang relative besar seperti rencana pendirian bank sampah.

3. Dukungan pemerintah setempat sebenarnya sangat besar, tetapi justru kendala dihadapi adalah masih rendahnya kesadaran masyarakat khususnya yang tinggal di sekitar bibir sungai karena persepsi mereka terhadap Sungai bukan hanya tempat untuk mengalirkan air tetapi juga tempat untuk mengalirkan atau mengikutkan sampah. Sehingga perilaku masyarakat di sekitar masih menjadikan Sungai Tawing sebagai tempat 
pembuangan sampah yang dianggap paling mudah dalam memusnahkan sampah dibandingkan jika harus ditimbun atau dibakar.

4. Ironisnya tempat pembuangan sampah yang ada di kecamatan pun juga berada di bibir sungai atau berada 3-5 meter dari Sungai. Sehingga kalau musim hujan tiba, praktis sampah yang dikumpulkan di TPA tersebut terikut sungai dan petugas tidak perlu membakarnya.

\section{Rencana Kegiatan Jangka panjang:}

a. Publikasi hasil kegiatan pelestarian lingkungan baik secara langsung melalui media masa, melalui workshop, dan mengikuti pameran di tingkat kecamatan seperti yang diselenggarakan setiap tahun di lapangan kecamatan kampak tanggal 17-18 Agustus 2011.

b. Mengadakan kerjasama dengan instansi pembina baik dari kecamatan maupun dari kabupaten dengan dinas atau instansi yang memiliki agenda dan program dalam bidang lingkungan Hidup (misalnya, kegiatan kecamatan untuk penanaman 1000 pohon dan konservasi sungai Tawing dengan pelarangan meracuni sungai).

c. Membangun jejaring dengan para pendamping dari Dinas Pertanian terutama dalam pengelolaan limbah rumah tangga menjadi pupuk organik

d. Menyusun buku panduan untuk kelompok sasaran yang berisi penjelasan mengenai: Kondisi lingkungan yang cenderung terus menurun, kesejahteraan masyarakat yang tergantung pada kualitas lingkungan hidupnya dan hak akan lingkungan hidup yang baik dan sehat serta prosedur apa yang akan dilakukan terkait dengan upaya pengelolaan lingkungan.

e. Revitalisasi dan penguatan kelembagaan dengan model kaderisasi, peningkatan kapasitas SDM dan management organisasi.

f. Pembiayaan dan Anggaran.

\section{Kesimpulan Dan Saran:}

Berdasarkan hasil penelitian diketahui bahwa sebagaian masyarakat di sekitar kawasan Sungai belum mengolah limbah domestik dengan recycle, namun 
model pengelolaan dengan cara reuse (menggunakan kembali) khususnya limbah plastik sudah dilakukan. Namun dari hasil pengamatan di lapangan menunjukkan bahwa kondisi sungai Tawing masih banyak sampah berceceran dan terbawa arus sungai dan bibir sungai, karena karena tempat pembuangan sampah dari pasar berada di bibir sungai. Hasil penelitian juga menujukkan bahwa sebagian besar yang membuang sampah ke sungai bukan penduduk setempat namun para pedagang dari pasar baik yang berjualan di toko-toko sepanjang anak sungai maupun para pedagang pasar seperti; pedagang ayam potong, limbah kotoran dan bulu ayam sebagaian besar dibuang ke sungai. Ditemukan juga peternak sapi yang membuang limbah kotorannya ke sungai. Di samping itu minimnya sanitasi pribadi (khususnya WC) bagi masyarakat di pinggiran Sungai Tawing (khususnya di wilayah Bendo Kidul dan Bogoran) sebagian masyarakat di wilayah tersebut menggunakan sungai Tawing untuk Kakus.

Namun pengolahan limbah domestik untuk pupuk organik dengan model recycle sudah banyak dilakukan di wilayah desa Senden Kec. Kampak. Pengolahan ini dipelopori pemuda karangtaruna dan komunitas pemuda peduli lingkungan (DPR Community) bekerjasama dengan Dinas Pertanian. Sebagian masyarakat yang mengolah limbah domestiknya menjadi pupuk organik rata-rata bekerja sebagai petani. Demikian juga masyarakat yang tinggal di desa Melis Kec. Gandusari. Sebagaian besar masyarakat yang bekerja sebagai petani yang juga mengolah limbah rumah tangga organiknya menjadi kompos secara mandiri dengan membuat 'pawuhan'. Larangan membuang sampah dengan diikuti pemberingan sanksi (membayar semen 2 sak) bagi pelanggarnya terbukti efektif, sehingga kualitas sungai sangat terjaga.

Kondisi ini sangat berbeda dengan kualitas sungai yang ada di kawasan Bendokidul kecamatan Kampak dan sekitarnya. Secara kasatmata kondisi sungai terkesan jorok, kotor dan berbau karena banyak sampah plastik yang terikut sungai dan kotoran seperti; bulu ayam dan kotoran manusia terikut arus sungai.

Strategi pemberdayaan yang dilakukan oleh komunitas pemuda antara lain melalui: perecanaan, program dan aksi, penguatan kelembagaan dan management organisasi, pengembangan jejaring dan kerjasama, serta peningkatan kapasitas 
SDM. Perencanaaan program serta aksi dilakukan dengan melakukan sosialisasi, pendampingan dan pengembangan jaringan dan kerjasama. Sosialisasi dan pendampingan dilakukan dengan menentukan kelompok sasaran yaitu; komunitas ibu-ibu rumah tangga/PKK, Komunitas pemuda dan karangtaruna, komunitas guru, komunitas pendamping dan mahasiswa. Sedangkan pengembangan jaringan dan kerjasama seperti yang sudah dilakukan dengan 'menggandeng' Dinas Pertanian untuk pengadaan mesin penggiling limbah domestik khususnya kotoran hewan (kambing) dan potongan sayuran.

\section{Daftar Pustaka}

Muktasor ,(ed), 2009, Pengantar Ilmu Lingkungan, ITS Press.

Mosse,Julia Cleves, 2002, Gender dan Pembangunan, Fifka Annisa.

Muhhamad, Syahri, 2009, Model Pemberdayaan Masyarakat Miskin di Sekitar Sungai Brantas, Penerbit Baitul Umma.

Salim, Emile, 1998, Pembangunan Berwawasan lingkungan, LP3ES.

Windiani, Pemberdayaan Masyarakat Lokal dalam Pengelolaan Hutan Pinus Di Kabupaten Trenggalek, dalam Jurnal Teknoling, Vol 3 No1 Tahun 2005.

Yuwono, dkk, 2009, Pelestarian Kawasan Sungai Ciliwung, Pasca Sarjana Universitas Indonesia.

Saribanon,dkk (2009), Forum Pasca Sarjana, Vol.32. No 2: Perencanaan Sosial Dalam Pengelolaan Sampah Permukiman Berbasis Masyarakat Di Kotamadya Timur.

Utami, dkk, (2008): Jurnal Transdisiplin, Sosiologi, Komunikasi, Dan Ekologi Manusia,Vol.02, N0.01: Pengelolaan Sampah Rumah Tangga Berbasis Komunitas: Teladan dari Dua Komunitas Di Sleman dan Jakarta Selatan.

Sudirman, (2009), MAKARA, SOSIAL HUMANIORA,VOl.13,No.2: Pengelolaan LingkunganDan Kondisi Masyarakat Pada Wilayah Hilir Sungai 